\title{
Could image rights solve issues raised by unwanted photography?
}

\section{Introduction: setting the scene}

It's a strange situation. In English law, photographs taken by an individual of another individual are legally owned by the photographer, ${ }^{1}$ who also enjoys a significant amount of control over the image, at least initially. ${ }^{2}$ Whilst the subject of the photograph (the 'photographed') might be the entire focus of the image, in law the 'photographed' presently lays very limited claims to the image or what happens to it in future. ${ }^{3}$ This means that there currently can be inadequate recourse for an individual who finds their image used against their wishes or without their knowledge.

The taking of photographs has become a fundamental aspect of everyday life, with few opportunities to 'escape' the camera's gaze, but often little thought is given as to what or whom is photographed and then what subsequently happens to the photograph. Thanks to technological developments, 'individuals can now post to an audience that previously would have been available only through the mass media', ${ }^{4}$ with the potential to share private and personal data on a global scale. Matters which formerly would only have been of relevance to the celebrity or public figure are now applicable to the ordinary person. This also means

\footnotetext{
${ }^{1}$ Under the Copyright, Designs and Patents Act 1988 (CDPA) a photograph is a copyrighted work under section 1(1)(a) and the photographer the owner, with a photograph included as an 'Artistic Work' under section 4(1)(a). ${ }^{2}$ Once an image is placed online, particularly on social media, control over what happens to it can be rapidly lost due to the potential for images to be shared and reposted - especially given how social media sites actively encourage individuals to share personal information.

${ }^{3}$ Save for in limited circumstances, for example under section 85 of the CDPA there exists a 'Right to privacy of certain photographs and films', where a person has for private and domestic purposes commissioned the taking of a photograph or film, and has the right not to have copies of the work issued, exhibited or shown in public; the tort of passing off as set out under Reckitt \& Colman Ltd v Borden Inc [1990] 1 All E.R. 873 and data protection considerations which relate to the publication of identifiable images of natural persons under the General Data Protection Regulation (Regulation (EU) 2016/679) (GDPR) - the implications of the GDPR will be given further consideration below.

${ }^{4}$ Jacob Rowbottom, 'To Rant, Vent and Converse: Protecting Low Level Digital Speech' (2012) 71 Cambridge Law Journal 355, 365.
} 
that images can be posted by third parties of other individuals, who have little control over the eventual reach of such an image. A recent example is the phenomenon of 'sharenting', a term used to describe the way in which parents share details of their children's lives online. ${ }^{5}$ Images can become particularly problematic when it is assumed that the photograph is what it purports to be; however, it must be kept in mind that images today can be digitally altered and objects or people can be manipulated or removed altogether, ${ }^{6}$ meaning that an image does not always portray the truth and context becomes of crucial relevance.

Difficulties can arise when a photograph that is not necessarily intrusive to one's privacy, but is nonetheless unwanted, is placed by one individual of another into the public domain. In an interconnected world where, particularly due to the impact of social media, sharing images of others has become second nature, this issue is of more relevance than ever. The tort of misuse of private information (developed from the breach of confidence claim ${ }^{7}$ ) is of limited use in such circumstances and will only provide recourse where the court asks what a reasonable person of ordinary sensibilities would feel if placed in the same position as the claimant and faced with the same publicity. ${ }^{8}$ The claim effectively has two stages, which requires a balancing of Convention rights - Articles 8 and $10:^{9}$

(1) Essentially the touchstone of private life is whether in respect of the disclosed facts the person in question had a reasonable expectation of privacy;

\footnotetext{
${ }^{5}$ See discussion in Stacey Steinberg, 'Sharenting: Children's Privacy in the Age of Social Media' (2017) 66 Emory L.J. 839, 842.

${ }^{6}$ House of Lords Select Committee on Science and Technology, 'Digital Images as Evidence' (House of Lords 1998) Fifth Report 1.1. <https://publications.parliament.uk/pa/ld199798/ldselect/ldsctech/064v/st0501.htm> accessed 03 September 2019.

${ }^{7}$ See Coco v A N Clark (Engineers) Ltd [1969] RPC 41.

${ }^{8}$ Campbell v MGN [2004] UKHL 22, Lord Hope at [92].

${ }^{9}$ European Convention on Human Rights 1950 (hereafter ECHR) (Convention for the Protection of Human Rights and Fundamental Freedoms, 4 November 1950, 213)
} 
(2) If so, does this expectation of privacy outweigh the publisher's (here, the photographer's) article 10 rights? ${ }^{10}$

Respectively, Articles 8 and 10 ECHR provide the following:

\section{Article 8: Right to respect for private and family life: ${ }^{11}$}

Article 8(1): Everyone has the right to respect for his private and family life, his home and his correspondence.

Article 8(2): There shall be no interference by a public authority with the exercise of this right except such as is in accordance with the law and is necessary in a democratic society in the interests of national security, public safety or the economic well-being of the country, for the prevention of disorder or crime, for the protection of health or morals, or for the protection of the rights and freedoms of others.

\section{Article 10: Freedom of Expression: ${ }^{12}$}

Article 10 (1): Everyone has the right to freedom of expression. This right shall include freedom to hold opinions and to receive and impart information and ideas without interference by public authority and regardless of frontiers. This Article shall not prevent States from requiring the licensing of broadcasting, television or cinema enterprises.

Article 10 (2): The exercise of these freedoms, since it carries with it duties and responsibilities, may be subject to such formalities, conditions, restrictions or penalties as are prescribed by law and are necessary in a democratic society, in the interests of national security, territorial integrity or public safety, for the prevention of disorder or

${ }^{10}$ Campbell (n 8) Lord Nicholls at [21].

${ }^{11}$ Article 8 ECHR 1950 (n 9).

${ }^{12}$ Article 10 ECHR 1950 (n 9). 
crime, for the protection of health or morals, for the protection of the reputation or rights of others, for preventing the disclosure of information received in confidence, or for maintaining the authority and impartiality of the judiciary.

This approach places significant weight on the application of Article 8 of the European Convention on Human Rights (hereafter ECHR), ${ }^{13}$ which takes into account 'all the circumstances of the case', including: the attributes of the claimant; the nature of the activity in which the claimant was engaged; the place at which it was happening; the nature and purpose of the intrusion; the absence of consent and whether it was known or could be inferred; the effect on the claimant; and the circumstances in which and the purposes for which the information came into the hands of the publisher. ${ }^{14}$ Whilst this allows for a broad range of circumstances to be considered, it still means that some situations will inevitably not lead to legal protection of an individual who may feel wronged at the taking or sharing of their image. For example, if a reasonable expectation of privacy is not demonstrated, the tort of misuse of private information will not be available. Furthermore, the 'reasonable expectation of privacy' test has been criticised for being outdated, unnecessary and of limited use to the everyday person, ${ }^{15}$ who may lack the necessary finance or knowledge to bring a claim. In considering all the circumstances, ${ }^{16}$ the application of the 'reasonable expectation of privacy' test is dependent on context, which means it varies from case-to-case and is not consistent. Despite having had opportunities to depart from the test or to clarify its

\footnotetext{
${ }^{13}$ Article 8 ECHR (n 11).

${ }^{14}$ Murray v Big Pictures [2008] EWCA Civ 446 Sir Anthony Clarke MR at [36].

${ }^{15}$ See for example Eric Barendt, 'A reasonable expectation of privacy': a coherent or redundant concept?' in Andrew T Kenyon (ed), Comparative Defamation and Privacy Law (Cambridge University Press 2016) 96; Eric Barendt, 'Problems with the "Reasonable Expectation of Privacy" Test' (2016) 8, Journal of Media Law, 129 and Rebecca Moosavian, 'Stealing 'souls'? Article 8 and photographic intrusion' (2018) Northern Ireland Law Quarterly, 69(4): 531, 546.

${ }^{16}$ Murray (n 14).
} 
application, instead the courts have continued to emphasise its relevance, adding additional factors which have contributed to the confusion. ${ }^{17}$

This article explores whether the introduction of image rights to English law would be an appropriate mechanism to deal with such issues. The author has carried out an empirical study, exploring attitudes towards the development of image rights, particularly focusing on privacy aspects,${ }^{18}$ and utilised the data from this. The benefits and drawbacks of such an approach are considered, and ultimately this article puts forward the case that the development of image rights is not required, instead a greater role can be played by education and social norms. As a preliminary point, it is useful to examine what is meant by the term 'image/publicity right'. Gillian Black explores the range of circumstances which may be covered by image/publicity rights - from 'the publication, without consent, of an innocent photograph or a young girl taken without her consent, to the interference with a commercial licence for use of a baseball player's image, arising from the defendant's use of the player's image with his consent'. ${ }^{19}$ One of the difficulties in considering image rights is that the same laws are attempting to deal with a wide range of different circumstances, which must be kept in mind during the discussion below. For the purposes of this article, the focus will lie more

\footnotetext{
${ }^{17}$ See for example Re JR38 [2015] UKSC 42 at [98] where Lord Toulson reiterated the use of the 'reasonable expectation of privacy' test, and added the additional factors of the age of the person involved, the context of the activity and the use to which the relevant material is put.

18 The empirical study constituted qualitative research interviews ('research interviews') and a pilot research survey (the 'Law and Photography Survey', hereafter LPS), carried out between 2015 and 2017 as part of a broader $\mathrm{PhD}$ research programme. This consisted of 21 elite interviews carried out with professionals in the field, including police, journalists and politicians - only a sample of relevant comments are included within this paper. Interviewees are given identifiers which reflect their role/position. It also includes a research survey carried out amongst 189 respondents (law students and the public). More information on the methodology can be obtained by contacting the author.

${ }^{19}$ See Aubry v Les Editions Vice-Versa (1998) 1 SCR 591 and Haelan Laboratories v Topps Chewing Gum Inc (1953) 202 F.2d 866 respectively in Gillian Black, Publicity Rights and Image - Exploitation and Legal

Control, (Hart Publishing, London, 2011) 11-12.
} 
on the first scenario, i.e. the extent to which image rights may cover the publication of innocent photographs taken without consent.

\section{Why do image rights matter to privacy?}

Photographs have long been seen as holding a special power, which makes them somehow more intrusive than the impact of text, and thus may be actionable where words alone would not be. In the words of Justice Ouseley, images have the potential to intrude 'in a peculiarly humiliating and damaging way'. ${ }^{20}$ As noted by Lord Nicholls of Birkenhead in Campbell, 'In general photographs of people contain more information than textual description. That is

why they are more vivid. That is why they are worth a thousand words'. ${ }^{21}$ Photography engages the traditional Article 10 freedom of expression vs. Article 8 privacy debate, with the interests of the photographer sometimes in direct conflict with those of the 'photographed'. Consequently, control over the image becomes a matter of key importance, which can be considered from two different perspectives, these being:

(a) Control exercised by the photographer; and

(b) Control exercised by the 'photographed'.

The photographer and the 'photographed' will often not be the same person, and they may therefore have competing interests at stake, with a conflict present between the wishes and desires of the photographer as opposed to the 'photographed'.

\footnotetext{
${ }^{20}$ See Theakston $v$ MGN Ltd [2002] EWHC 137 (QB) Ouseley J at [78].

${ }^{21}$ Campbell (n 8) Lord Nicholls at [31].
} 


\section{What other protections exist for the 'photographed'?}

As outlined earlier, existing protection for individuals who find their image (taken by others) shared online is limited. The main mechanisms currently existing include:

\section{i) Intellectual Property Law}

Whilst intellectual property law in England does not extend to cover image rights, some protection is available, including copyright provisions and trade mark protection.

\section{a) Copyright}

Under Copyright law, there is a right to privacy of certain photographs and films under section $85 \mathrm{CDPA},{ }^{22}$ which provides under subsection 1 :

A person who for private and domestic purposes commissions the taking of a photograph or the making of a film has, where copyright subsists in the resulting work, the right not to have-

(a) Copies of the work issued to the public,

(b) The work exhibited or shown in public, or

(c) The work communicated to the public.

This provides some protection, although only in certain circumstances. It requires that the photograph/film is commissioned by an individual for private and domestic purposes, and thereby will exclude situations which might cause concern to the individual featured, such as where they are unaware of the existence of the photograph, or where it is taken by another individual, thus is limited in its application.

\section{b) The tort of passing off}

\footnotetext{
${ }^{22}$ As provided for under section 85 CDPA 1988 (n 1).
} 
The tort of passing off was restated in Reckitt \& Colman Ltd $v$ Borden Inc, ${ }^{23}$ with Lord Oliver setting out the 'Classic Trinity' of the claim, including that:

(1) The goods or services have acquired goodwill or reputation in the marketplace that distinguishes such goods or services from competitors;

(2) The defendant misrepresents his goods or services, either intentionally or unintentionally, so that the public may have the impression that the offered goods or services are those of the claimant; and

(3) The claimant may suffer damages because of the misrepresentation.

Following the cases of Irvine v Talksport ${ }^{24}$ and Fenty $v$ Arcadia Group Brands Limited, ${ }^{25}$ the tort of passing off has been successful in protecting famous claimants from images of themselves being used by others, but this is very much decided on a case-by-case basis, and in any circumstance is unlikely to extend to a person who is not in the public eye (i.e. does not have goodwill or reputation within the marketplace).

\section{c) Trademarks}

Under section 1 of the Trade Marks Act 1994, trade mark protection extends to protect 'any sign capable of being represented graphically which is capable of distinguishing goods or services of one undertaking from those of other undertakings', and requires registration. Whilst it is possible that this protection extends to an image, this is only

\footnotetext{
${ }^{23}$ Reckitt \& Colman Ltd v Borden Inc [1990] 1 All E.R 873.

${ }^{24}$ Irvine v Talksport [2003] 2 All ER 881 (CA). A doctored photograph of racing driver Eddie Irvine had been used in advertising for a radio station and the claimant was able to bring an action for passing off.

${ }^{25}$ Fenty v Arcadia Group Brands Limited [2015] 1 WLR 3291 (CA). The case concerned the use of photographs of pop star Rihanna used on T-Shirts sold by Topshop without her authorisation. The singer was successful in bringing an action for passing off to prevent this.
} 
likely to be relied upon by celebrities and therefore is of limited use to the every day person who wishes to prevent unwanted photography.

\section{ii) Criminal law}

Various protection is also given to the 'photographed' through Criminal laws, but, in order to rely upon such protection, requires the photographer to have acted in a manner that contravenes the criminal law, and therefore deemed as attracting criminal punishment, including Harassment under the Protection from Harassment Act 1997, Voyeurism under the Sexual Offences Act 2003, Image-based sexual abuse under s33 of the Criminal Justice and Courts Act 2015 and the recent introduction of a law on Upskirting under the Voyeurism (Offences) Act 2019.

\section{iii) Data Protection}

Data Protection, particularly under the General Data Protection Regulation (GDPR), ${ }^{26}$ aims to give individuals more control over their personal data. Applying to the processing of data relating to identifiable, natural persons, the GDPR provides some protection for individuals whose image is shared. ${ }^{27}$ This can apply to photographs, as the publishing of information about identifiable individuals (including images) falls within the remit of data protection. ${ }^{28}$ Where it does, the photographer must comply with the data protection principles, as set out under Article 5 of the GDPR. ${ }^{29}$ Data must also have a basis for lawful processing which, for photographers, will usually concern consent (which must be freely given, specific, informed and an unambiguous indication of the individual's wishes) or legitimate interests. ${ }^{30}$ The

\footnotetext{
${ }^{26}$ General Data Protection Regulation (Regulation (EU) 2016/679).

27 'Personal data' includes 'any information relating to an identified or identifiable natural person ('data subject'); an identifier such as a name, an identification number; location data, an online identifier to one or more factors specific to the physical, physiological, genetic, mental, economic, cultural or social identity of that natural person' (Article 4(1) GDPR) (n 26).

${ }^{28}$ Lindqvist C-101/01 [2004] QB 1014; Ryneš C-212/13 (2014).

${ }^{29}$ Article 5 GDPR sets out the data protection principles to be complied with (n 26).

${ }^{30}$ The lawful bases for processing data are set out in Article 6 GDPR (n 26).
} 
GDPR also gives individuals rights in respect of their data, and for the purposes of this article the most relevant is the 'right to erasure' under Article 17. However, Article 2(2)(c) of the regulation does allow for a Personal Use exemption, which provides that it will not apply to the processing of personal data 'by a natural person in the course of a purely personal or household activity' ${ }^{31}$ This suggests that for the everyday photographer, the provisions may not be applicable, and thus protection for the 'photographed' is limited.

Given the limitations of the protections outlined above, here it will be considered whether image rights can be an adequate remedy to deal with concerns raised by undesirable or unwanted photography.

\section{The approach towards image rights in English Law}

Traditionally, English Courts have upheld the freedom to photograph as part of everyday life, in doing so relying upon the New Zealand decision in Hosking $v$ Runting, ${ }^{32}$ which noted that photographs taken in a public street are to be taken as one of the ordinary incidents of living in a free community. ${ }^{33}$ Consequently, English law has been reticent to recognise image rights, with English law recognising 'neither a right to one's image nor a general right to privacy (or personality right)' 34 Indeed, '...the idea of rights or control over image or personality is, in many ways, alien to our legal culture', ${ }^{35}$ and has been rejected by the courts

\footnotetext{
31 Article 2(2)(c) GDPR (n 26).

32 [2003] 3 NZLR 385 Randerson J at [138].

${ }^{33}$ See for example Campbell (n 8) Lord Hope at [122].

${ }^{34}$ Katharina von Bassewitz, 'Hard times for Paparazzi: Two Landmark Decisions Concerning Privacy Rights Stir up the German and English Media' (2004) 35 International Review of Intellectual Property and Competition Law, 642, 642.

${ }^{35}$ Brad Sherman and Felicity Kaganas, 'The Protection of Personality and Image: An Opportunity Lost' (1991) 13 EIPR 340.
} 
in the past. ${ }^{36}$ This is reflected in the view of Patten J in Murray v Express Newspapers, who held that:

If the law is such as to give every adult or child a legitimate expectation of not being photographed without consent on any occasion which they are not, so to speak, on public business then it will have created a right for most people to the protection of their image. ${ }^{37}$

Image rights are often seen as a fundamental aspect of one's personality and, where they exist, controls may include the obtaining of consent when the photograph is taken, not just when it is published. However, the existence of such rights could pose a serious threat to freedom of expression, which is protected under Article 10 ECHR. ${ }^{38}$ The photograph itself is now accepted as an art form in its own right ${ }^{39}$ and the photographer regarded as an artist. ${ }^{40}$ Whilst freedom of expression covers the publication of photographs, it must be balanced against the rights of others, as stated in von Hannover: 'Although freedom of expression also extends to the publication of photos, this is an area in which the protection of the rights and reputation of others takes on particular importance'. ${ }^{41}$ In such circumstances, where Articles 8 and 10 ECHR come into conflict, Lord Steyn's "ultimate balancing test" (as set out in $R e S$ ) comes into force, providing:

First, neither [arts 8 or 10] has as such precedence over the other. Secondly, where the values under the two articles are in conflict, an intense focus on the comparative

\footnotetext{
${ }^{36}$ See for example Baroness Hale in Campbell (n 8), who was clear to emphasise that the creation of an image right was not the intention of the courts, stating that photography being covert would not be enough to make information private: 'We have not so far held that the mere fact of covert photography is sufficient to make the information contained in the photograph confidential. The activity photographed must be private' at [154].

${ }^{37}$ Murray v Express Newspapers [2007] EWHC 1908 (Ch) Patten J at [65].

${ }^{38}$ Article 10 (n 12).

${ }^{39}$ See for example Lisa Gye, who comments on how the photograph has had to fight against the prejudices of the art establishment in order to be accepted, 'Picture This: the Impact of Mobile Camera Phones on Personal Photographic Practices' Continuum: Journal of Media \& Cultural Studies (2007), 21(2), 279, 282

${ }^{40}$ George Chernoff \& Hershel Sabin, Photography and the law $\left(4^{\text {th }}\right.$ edn, American Photographic Book Publishing Co., New York, 1971) 96.

${ }^{41}$ von Hannover $v$ Germany [2004] EMLR 379 at [59].
} 
importance of the specific rights being claimed in the individual case is necessary. Thirdly, the justifications for interfering with or restricting each right must be taken into account. Finally, the proportionality test must be applied to each. For convenience I will call this the ultimate balancing test. ${ }^{42}$

The factors to be taken into account include: The contribution made to a debate of general interest; the role or function of the person concerned and the nature of activities; the prior conduct of the person concerned; the content, form and extent of dissemination; the context and circumstances in which the published photographs were taken; the method of obtaining the information and its veracity; and the severity of the sanction imposed on the publisher. ${ }^{43}$

Especially in view of technological and societal developments, the question remains: should image rights be considered in England and Wales?

\section{What would the introduction of image rights achieve?}

A matter of some contention, image rights enable an individual (usually a well-known public figure) to control the dissemination of their image. As photographs become ever more prevalent within society, perhaps less thought is given to the individual's rights; as Beddard commented in 1995: '...the photograph and the ability to record someone's likeness instantaneously is taken for granted to such an extent that the rights of the individual may

\footnotetext{
${ }^{42}$ Re S (A Child)(Identification: Restrictions on Publication) [2004] UKHL 47 Lord Steyn at [17]

${ }^{43}$ Axel Springer AG v Germany (App no 39954/08) (2012) 227 ECHR at [89] and von Hannover v Germany (No 2) [2012] EHRR 15.
} 
with similar ease be ignored'. ${ }^{44}$ Perhaps, as a reflection of society, this is only easier in today's connected world.

Although the introduction of image rights would undoubtedly strengthen the protection available to individuals in terms of the use of their image, and provide personal autonomy to choose what happens to their image, at what cost would this be to the freedom to photograph? The freedom afforded to individuals within England and Wales to take and share photographs is a fiercely guarded liberty, particularly by photographers and journalists. However, the piecemeal way in which protection is developing for individuals, particularly in respect of their privacy protection, leaves photographers confused and unclear as to the application of the law. The introduction of image rights would potentially introduce a certain degree of clarity to the law surrounding photography, making it easier for individuals to establish when they can enforce control over their image, and acknowledges that there are some groups with whom individuals are happy to share information, and others with whom they are not. ${ }^{45}$ It would also clarify the situation for photographers, who would have a clearer understanding of appropriate taking and use of images, and would effectively restrict the taking of photographs without the consent of the individuals featured. Introducing image rights would be a significant change to the approach currently taken towards photography (which is at present not reliant upon the concept of consent). This would change the focus to obtaining prior

\footnotetext{
${ }^{44}$ Ralph Beddard, 'Photographs and the Rights of the Individual' (1995) 58 Modern Law Review 771, 771.

${ }^{45}$ danah boyd emphasises that there are different levels of 'publicness' - for example an individual might be happy to share information with 'friends', but not others e.g. work colleagues or vice versa, danah boyd, 'Privacy and Publicity in the Context of Big Data' (Talk, North Carolina, 29 April 2010) <www.danah.org/papers/talks/2010/WWW2010.html> boyd has deliberately opted not to capitalise her name: see 'what's in a name?' 'danah michele boyd' <http://www.danah.org/name.html > accessed 30 December 2019.
} 
consent, whereas presently the majority of disputes have related to not to the taking, but the later dissemination and sharing of images. ${ }^{46}$

However, such a move would not be popular, particularly amongst the media. Furthermore, it can be questioned to what extent such a right would give control to the individuals seeking this, as one of the key criticisms of image rights has been the limited use/availability of publicity rights to the ordinary, everyday person who may not be seen as a public figure but merely wishes to control the use of their image within the public domain. ${ }^{47}$ Given the sheer number of images taken, this makes control over them difficult and practicalities have to become an issue of key importance. Progressing technology such as social media challenges the very concept of control, particularly as it has the capability for anyone to post images online, and 'tag' others within these, therefore the idea of giving control to the 'photographed', apart from removing the 'tag', becomes complicated.

Consequently, the issue and relevance of 'prior publicity', i.e. one's approach towards the sharing and dissemination of one's own image, has been given considerable attention by the courts, albeit traditionally in the sphere of celebrities ${ }^{48}$ - where prior conduct, such as actively courting publicity, can limit the effectiveness of any privacy claim. ${ }^{49}$ However, as

\footnotetext{
${ }^{46}$ For example, in Campbell (n 8), Lord Nicholls [30] noted that the complaint did not relate to the taking of photographs, but the publication.

${ }^{47}$ See for example Eugenia Georgiades, who notes that the US right of publicity is 'now effectively limited to celebrities' in 'Protecting the image: applying a right of publicity to images uploaded on social networks' (2019) European Intellectual Property Review, 41(1), 38, 39.

${ }^{48}$ See Weller \& Ors v Associated Newspapers Ltd [2015] EWCA Civ 1176 at [178]. In this instance the approach taken by the parents of the children which had resulted in few photographs being in the public domain was relevant.

${ }^{49}$ Prior conduct of the individual is taken into account by the courts, but will depend on the circumstances of each case. For example, in Mr Edward RocknRoll v News Group Newspapers Ltd [2013] EWHC 24 (Ch) it was held that publication of photographs on Facebook did not mean that there was no privacy left to be protected and an injunction was still granted.
} 
with many of the issues discussed in this article, today prior publicity potentially applies also to the everyday person, who can share information online and can thus perhaps be viewed as a public figure. ${ }^{50}$ Prior publicity is particularly relevant in relation to children, where 'The court can attribute to the child reasonable expectations about his private life based on matters such as how it has in fact been conducted by those responsible for his welfare and upbringing'. ${ }^{51}$

\section{Does an image right already exist in English law?}

Whilst protection for the individual's image has undoubtedly been strengthened over time, the English courts have emphasised that the creation of an image right is not their aim - for example in Douglas v Hello! Lord Walker commented that: 'Their [the Douglas's] claims come close to claims to a 'character right' protecting a celebrity's name and image such as has consistently been rejected in English law' ${ }^{52}$ and, in Campbell, Baroness Hale was clear to emphasise that the creation of an image right was not the intention of the courts, noting that 'Unlike France and Quebec, in this country we do not recognise a right to one's own image... We have not so far held that the mere fact of covert photography is sufficient to make the

\footnotetext{
${ }^{50}$ There is some debate as to when a person becomes a 'public figure/celebrity', and this will be a matter dependent on the circumstances of each case. See for example the Advertising Standards Authority (ASA) Ruling on ThisMamaLife and the advertising of Phenergan Night Time tablets - in this instance 32,000 followers was seen as a significant following and thus amounted to a public figure, enough to result in an advertising ban on medicines applying in this particular case, 'ASA Ruling on Sanofi UK in Association with This Mama Life' ban upheld' (03 July 2019) <https://www.asa.org.uk/rulings/sanofi-uk-A19-557609.html> accessed 06 December 2019. Kirsty Hughes criticises the concept of the 'public figure' for being ill-defined and flawed in her article 'The public figure doctrine and the right to privacy' Cambridge Law Journal (2019) 78(1), 70-99.

${ }^{51}$ Murray v Express Newspapers (n 37) Patten J [2007] EWHC 1908 (Ch) at [23].

52 Douglas and another and others $v$ Hello! Limited and others [2007] UKHL 21. There were a number of cases concerning photographs taken at the wedding of Michael Douglas and Catherine Zeta Jones. Exclusive rights to publish the wedding photographs had been agreed with OK! Magazine for a fee of $£ 1$ million, but Hello! had managed to get access to the wedding and published the photographs. The claim under privacy law by the Douglas's and breach of confidence by OK! were both successful by a majority of 3:2 before the House of Lords, which restored the earlier High Court decision.
} 
information contained in the photograph confidential. The activity photographed must be private'. ${ }^{53}$

However, it can be argued that the recent judgment in Weller $^{54}$ effectively gives rise to image rights in practice, as:

(1) Article 8 - Right to respect for private and family life - was still infringed even though the children were not aware that the photographs were taken/existed, and

(2) The photographs did not reveal private information, yet still came within the tort of Misuse of Private Information.

The case of Weller concerned photographs published in the MailOnline which showed singer Paul Weller and his children out shopping in the street and relaxing in a café in California. Seven unpixelated photographs had been published despite the fact that there had been no parental consent, Weller had requested that the photographer stop, and an assurance had been given that the photographs would be pixelated. The defendant (Associated Newspapers Ltd) was found liable for misuse of private information and breach of the Data Protection Act 1998. The result of the case was effectively to extend the law to mean that there may be an expectation of privacy in circumstances where privacy considerations would not usually be present and, in reaching the decision, a number of factors were seen as having an influence including: lack of consent, identifiability, prior publicity, the relevance of the status of the child, and whether there is a family element.

\footnotetext{
${ }^{53}$ Campbell (n 8) Baroness Hale at [154].
}

${ }^{54}$ Weller (n 48). 
However, one can discern that English law is still a considerable distance from introducing image rights as seen in other jurisdictions as, in Weller, ${ }^{55}$ the 'critical factor' in establishing the expectation of privacy was the identification of the children by surname, in addition to their photograph. ${ }^{56}$ As a result, the Weller decision continued to develop English law in line with the existing law on photography of children and in accordance with decisions of the European Court of Human Rights (in particular the von Hannover cases),${ }^{57}$ reliant upon the particular facts in the present case (Weller). ${ }^{58}$

\section{Some comparative insights}

The current situation sets England and Wales at odds with many of their European counterparts and further afield where image or publicity rights exist. It is useful to consider the situation in a few selected jurisdictions, which have been chosen due to image rights having either existed for a significant period of time (United States), recently been introduced (Guernsey), or reflective of the jurisdictional approach to privacy, which tends to be more pro-privacy than the situation seen in England and Wales (France, Germany and Greece). As Sherman and Kaganas identified as early as 1991:

In short, in today's world the image and other attributes of the personality are increasingly reified: UK law has, on the whole, failed to take account of this change. This failure is particularly marked when comparisons are made with other legal systems, for example, both France and Germany have developed rights of personality

\footnotetext{
${ }^{55}$ Weller (n 48).

56 ibid at [63].

${ }^{57}$ Von Hannover v Germany [2004] EMLR 379; (2005) 40 EHRR 1; Von Hannover v Germany (No. 2)(2012)

55 EHRR 15; Von Hannover v Germany (No.3)(2013) Application No 8772/10.

${ }^{58}$ Weller (n 48).
} 
which, in the appropriate circumstances, enable the individual to control the uses that are made of his or her attributes. ${ }^{59}$

For example, the United States, which, although similar to the UK in having no requirement to obtain consent of individuals prior to photographing, has well established publicity rights that enable a person (usually a public figure/celebrity) to control the commercial use of their identity. ${ }^{60}$ In respect of this right, Georgiades identifies four elements that must be satisfied, including: (1) that the plaintiff's identity has been used; (2) for the defendant's advantage, commercial or otherwise; (3) without the plaintiff's consent; and (4) there is a resulting injury, before further commenting that in the American jurisprudence it has usually been construed narrowly, in that the use of an image must be for commercial purpose, ${ }^{61}$ which in practice limits its effectiveness for the everyday person.

Conversely, protection is more widespread in Germany, where a general right of personality exists under the Constitution, ${ }^{62}$ guaranteeing both human dignity and the right to develop one's personality: 'Since the figure of a person is the characteristic feature of the individual to represent himself in the social context, the law protects the right of the person to determine and control the manner in which his image is presented in public' ${ }^{63}$ In a similar manner to the approach taken in Germany, privacy in France is strongly protected under the Civil Code,${ }^{64}$ and for French philosopher and lawyer Edelman, image rights must exist (his

\footnotetext{
${ }^{59}$ Sherman and Kaganas (n 35) 343.

${ }^{60}$ Publicity rights constitute part of the tort of a right of privacy, which includes: (1) intrusion upon the plaintiff's seclusion or solitude or into his private affairs; (2) public disclosure of embarrassing private facts about the plaintiff; (3) publicity which places the plaintiff in a false light in the public eye; and (4) appropriation, for the defendant's advantage, of the plaintiff's name or likeness as stated in Warren \& Brandeis, 'The Right to Privacy' (1890) 4 Harvard Law Review 193, 197. Also see Haelan Laboratories Inc (n 19).

${ }^{61}$ Georgiades (n 47) 39.

62 Articles 1, 2 (1) of the German Basic Law 1949.

${ }^{63}$ Arnold Vahrenwald, 'Photographs and Privacy in Germany’ (1994) 5 Entertainment Law Review 205, 205.

${ }^{64}$ Privacy is protected under Article 9 of the French Civil Code 1970.
} 
viewpoint is perhaps due to the legal context in France, which takes a far more protective stance towards an individual's privacy than is currently seen in England):

There is a contradiction whereby the photographer and the film-maker produce the real, but that in that production they encounter a real which already belongs to someone else. The photographer can indeed photograph a face, but that face belongs to someone, the person who is photographed and who owns the face. The production of the subject therefore finds its necessary limitation in the subject himself. ${ }^{65}$

In Reklos and Davourlis v Greece ${ }^{66}$ photographs were taken of a baby in a Greek hospital without the consent of the parents. The right to protection of the baby's image (as a minor) lay with the baby's parents, thus the fact that no consent was given by them had been relevant. ${ }^{67}$ Part of the court's reasoning was that as personality presupposes the right to control of the image, because the negatives were retained by the photographer they could have been used at a later date against the wishes of the parents. ${ }^{68}$ In today's digital society, such problems are only amplified, with the sharing of images on social media exacerbating the situation.

Guernsey introduced a law on image rights in $2012 .{ }^{69}$ The Guernsey law offers registered image rights, applicable to anyone currently in the public eye or who may be in the future. They are seen as property rights acquired by registration of a 'personality' in Guernsey's Register of Personalities and Images, and relate to a person's essential brand; i.e. the name by

\footnotetext{
${ }^{65}$ Bernard Edelman, Ownership of the Image: Elements for a Marxist Theory of Law (Routledge \& Kegan Paul 1979) 43.

${ }^{66}$ Reklos and Davourlis v Greece [2009] ECHR 200.

${ }^{67}$ The right to personality is protected under Article 57 of the Greek Civil Code.

${ }^{68}$ Reklos (n 66) at [40].

${ }^{69}$ Under the Image Rights (Bailiwick of Guernsey) Ordinance 2012.
} 
which the person is known. Although it is not required that the personality is well-known at the time of registration, 'in order to claim infringement, the personality will have to be recognised by a wide or relevant sector of the public (in any part of the world), at the time of alleged infringement' ${ }^{70}$ thus again limiting applicability to the everyday person.

However, González illustrates how the relationship between the photographer and the 'photographed' is not straightforward and could ultimately lead to a clash of rights, when both image rights and copyright exist:

The right to one's own image and copyrights could eventually clash if the photographer makes use of an image of his authorship without having the permission of the portrayed person. In short, the photographer must have the portrayed person's consent in order to capture and use the picture...the existence of such consent is a conditio sine qua non for copyrights to be claimed over a picture featuring the image of an individual. If the consent of the photographed person is unequivocal, then copyrights prevail over image rights. ${ }^{71}$

The potential for global application of the law and subsequent jurisdictional challenges must also be kept in mind, a point illustrated by the decision of the European Court of Justice in the joined cases of eDate Advertising GmbH $v$ X and Olivier Martinez, Robert Martinez $v$ MGN Limited. ${ }^{72}$ The latter case concerned the publication of images of Olivier Martinez in

\footnotetext{
${ }^{70}$ Jason Romer and Kate Storey, 'Image Is Everything! Guernsey Registered Image Rights' (2013) 24 Entertainment Law Review 51, 53.

${ }^{71}$ Lennin Hernández González, 'Is a Selfie Worth a Thousand Words? The Right to Protection of One's Image from a Belgian Perspective’ (2017) 28 Entertainment Law Review, 3, 6.

72 Joined cases - Cases C-509/09 and C-161/10 [2011] ECR I-10269.
} 
the digital version of the Sunday Mirror, accessed in Paris, the Court holding that where the publication can be downloaded creates the jurisdiction for action to be taken.

Whilst the existence of image rights seeks to allow individuals control over the manner in which their image is presented in public, there are a number of significant limitations; namely that the individual will usually need to be a public figure or well-known and they may need to register their interest. To effectively address the issue of unwanted photography, any image right within England would need to be broadly framed to be applicable to the everyday person and not only public figures, but, as with any broadly framed law, it would run the risk of being overly-restrictive towards photography and limiting freedom of expression. To assess whether the development of image rights would be beneficial in English Law, this paper will make use of interview and survey data carried out into the topic between 2015$2017 .^{73}$

\section{What do the public think? An anecdotal insight}

Whether specific image rights could or should develop in English law was a matter explored through both research interviews ('research interviews') and a pilot research study (the 'Law and Photography Survey', hereafter the 'LPS'), which sought to establish whether such a development would be supported both theoretically and practically. ${ }^{74}$ It was established that

\footnotetext{
${ }^{73}$ For more information on the methodology see $\mathrm{n} 18$ above \& $\mathrm{n} 74$ below.

${ }^{74}$ The research interviews were carried out with 21 individuals and, together with the Law and Photography survey, were part of a broader PhD research project. The data was collected between 2015 and 2017. The aim of the exploratory survey (the LPS) was to identify current understanding of the law as applicable to the taking and sharing of photographs, attitudes towards photography and how this might relate to the law's treatment of photography in the future. It was targeted at two main groups - law students and members of the general public who were over 18 years old and based in England and Wales at the time of completing the survey. It took the form of two identical questionnaires completed by the different groups. For the purposes of this article, their responses are considered as one group. The total sample size was 189 , although numbers responding to each
} 
for respondents to the LPS, taking photographs is a critical part of everyday life, with $91 \%$ taking photographs for 'memories', $84 \%$ to 'capture moments', $80 \%$ for 'leisure' and $74 \%$ 'to share with others'. Current understanding of law was also explored, with over $60 \%$ of respondents agreeing or strongly agreeing with the statement: 'I need an identifiable person's permission to publish an image of them on the internet'. Just under $40 \%$ were undecided or agreed with the statement: 'Images I take belong to the person photographed'. The level of confusion evident from respondents is perhaps not surprising, given the complex nature of laws applicable, but nevertheless does demonstrate the importance given by the public to the individual's rights (i.e. the 'photographed'), a position not currently reflected in law, and emphasises a need for greater education and understanding in this area.

Attitudes towards being photographed by a stranger in the street were also explored through the LPS, relating to how an individual perceives the importance of controlling their image. $10 \%$ of LPS respondents said that they would object in all circumstances, a further $46 \%$ noting that this would depend on the situation, with the remainder stating that they would not object. The qualitative responses from the $46 \%$ suggested that the majority took the viewpoint that if they were photographed incidentally as part of the background this would not pose a problem, but if they were featured/identified this would change the situation. For example:

- 'If I was part of a general crowd then that's OK and I have no expectations of total privacy. However, if I was the main or one of the main subjects then I 
would expect to be asked permission before it was shared and I would want to know how it would be shared'.

Of course, photographs taken by strangers were not the only matter of concern, sometimes it is photographs taken by those known to the 'photographed' that can cause significant problems. For example, in relation to photographs posted by parents, an interviewee said:

I mean, stuff gets posted online and what's really bad is, in sort of quasi Facebook terms, proud parents sharing pictures of their lovely daughters, either pre-teen or teen, posing up in the most inappropriate ways...And that, of course, is going to be a digital record that children are going to have to live with because their parents put it online (Academic: Ex-Journalists/Law).

Another said:

...I'm always horrified about the parents who put all these photos up of their kids, I sort of think - your kid has no choice in this (Activist).

Responses to having one's own image shared by others were also explored in the LPS, with some $85 \%$ of respondents having had the experience of their image being shared. Responses varied from those who were not worried about having their image shared online, largely where they saw the photograph as having a positive impact, personified by comments such as 'Proud to be in their picture', through to those who preferred that permission should be obtained first, wishing to seek control of the image. Typical comments included: 'I like to be aware that it is being posted and therefore have some control', through to 'ok because I have said it's ok to share'. At the other end of the scale were those that took a more negative 
approach to their image being shared, saying 'Don't like my own photo being used' and 'uncomfortable'. Some even felt quite annoyed at the use of their image in this way: 'I was quite angry about having my image shared on social media without my permission'.

These responses demonstrate a desire for control over unwanted images for a number (albeit not all) of respondents, which becomes a particular issue when considered in context with the concept of the perceived permanency of images. Ofcom research has outlined how 'for many, retaining control of their online image is important',${ }^{75}$ and suggests an increased role for consent prior to the taking/sharing of images. Consequently, on the whole, survey respondents to the LPS stated they would support an increase in protection of rights for the individual so that their image (photograph) could not be used or published by others without their consent, with 55\% agreeing, 27\% not sure, and 18\% disagreeing. Respondents were also asked for their qualitative views on the matter, which varied from those strongly in favour of an increase in rights (largely subject to a public interest exception), to those who were significantly less receptive to the idea. Comments included:

- 'Very important but possibly expensive and logistically difficult to enforce. Moving towards making it the social norm could help...?'

- 'In certain circumstances this would be appropriate. However the phrase 'live by the sword, die by the sword' springs to mind. Those who court publicity and make a living by it, especially those campaigning with a message, should not be unhappy when people use those same tools to establish they are fraudulent or a hypocrite... Those who value privacy should be given privacy'.

- 'Impractical. At what point does someone become identifiable in a crowd?'

\footnotetext{
${ }^{75}$ Children's Commission for England, 'Growing Up Digital' (Report, January 2017) 13 $<$ https://www.childrenscommissioner.gov.uk/publication/growing-up-digital/> accessed 12 September 2019.
} 
- 'I think it depends on the specifics of this rule. A blanket ban on publishing a picture without the consent of every person in it is impractical and unnecessary. However, in certain cases I think consent is required'.

Research interviewees tended to be less receptive towards the notion of increased image rights, which is perhaps attributable to their professional roles, commenting that the result would be that:

- 'It is going to create even more confusion' (Academic: Ex-Journalist/Law)

- 'As an organisation I don't think we would want to go down that road, that you'd have to get written consent for every photograph that you take in a public area, I think that would put restrictions on photographers that we, and our membership certainly wouldn't be comfortable with' (Photographic Organisation).

The difficulty with making consent to photography a requirement is that whilst this would serve to protect an individual's rights, it would come at a significant cost to freedom of expression, and would perhaps be akin to an image right, if images taken without consent could not be shared. However, collectively and crucially, the viewpoints given above suggest anecdotally that the law in its current form misses the desired and needed protection for individuals in respect of their image, but that this issue needs to be addressed sensitively for all involved. ${ }^{76}$ Whilst the introduction of an image right in its traditional sense may be a step too far, it is clear that some change is required to move society in line with the public's expectations and development of social norms, enabling the law to adapt to changing cultural and societal circumstances. Ways in which this could be achieved are discussed below.

\footnotetext{
${ }^{76}$ In addition to findings from the LPS, this is supported by Ofcom research which found that $75 \%$ of social media/messaging site users disagreed with the statement 'It is OK to share a photograph or video of other people without their permission' Ofcom, 'Adults' Media Use and Attitudes Report' (2018) 147 <https://www.ofcom.org.uk/_data/assets/pdf_file/0011/113222/Adults-Media-Use-and-Attitudes-Report2018.pdf> accessed 06 December 2019.
} 


\section{Conclusion: Development of Social norms and Education}

It is asserted that many of the issues discussed in this article relate to the issue of control over unwanted images, with image rights being one mechanism of exercising control. The responses to the Law and Photography Survey indicate that the public already assume and expect greater control over the individual's image. It is however, suggested that the situation can be addressed without the need for the development of image rights, as these may be a costly, impractical and unnecessarily disproportionate reaction and restriction to the freedom to photograph; instead the issue could be appropriately dealt with through good practice and education, encouraging consent and responsible photography practices.

Dicta from Campbell suggests that no liability for taking photographs without consent will arise; Lord Hoffman stating that '[t]he famous and even the not so famous who go out in public accept that they may be photographed without their consent, just as they may be observed without their consent'. ${ }^{77}$ Today, when determining whether a reasonable expectation of privacy arises, ${ }^{78}$ lack of consent is taken into account through the Murray factors. Whether consent should become a stand-alone requirement to the taking and sharing of images is a matter of some contention. Whilst respondents to the LPS were broadly in favour of consent being obtained prior to the taking and sharing of images, ${ }^{79}$ interviewees spoken to as part of this research tended to be less in favour of obtaining consent prior to the taking and sharing of photographs (although perhaps this can be attributed to their professional roles, e.g. as journalists/photographers, as opposed to thinking about their own rights, as was asked of respondents). For example, a Journalist commented: 'Oh it just

\footnotetext{
${ }^{77}$ Campbell (n 8) Lord Hoffman at [73].

${ }^{78}$ Murray (n 14) at [36].

$7955 \%$ survey respondents to the LPS stated they would support an increase in protection of rights for the individual to mean that their image (photograph) could not be used or published by others without their consent.
} 
becomes ridiculous at that point, otherwise it becomes like "Oh you can't look at me until I've given my permission to look at me"".

The danger of making consent a mandatory requirement would, in effect, be to create an image right, and the ubiquitous nature of both photography and social media would provide huge challenges to enforceability and application, both in terms of when such a requirement would apply and how it relates to a potential (different) future use of the image. However, the courts have already made a distinction between unknown crowd images and identifiable images, which would set a reasonable differentiation as to when consent should be sought. ${ }^{80}$ Obtaining consent as good practice prior to both the taking and sharing of photographs would be a progressive step forward, as consent helps an individual to feel empowered over his/her image $^{81}$ and builds on the idea of individual autonomy, ${ }^{82}$ as well as moving the situation in line with the public's existing expectations. ${ }^{83}$ Current laws, including Data Protection, ${ }^{84}$ give matters such as consent more importance than in the past (particularly where relied upon as the legal basis for processing data, and outside of the personal use exemption) but it remains to be seen as to the extent to which this will apply to photographers.

\footnotetext{
${ }^{80}$ See Weller \& Ors $v$ Associated Newspapers Ltd [2014] EWHC 1163 (QB) Dingemans J at [171].

${ }^{81}$ This is particularly the situation when the photograph is seen holding power itself, as argued by Flusser: 'Photographers have power over those who look at their photographs, they program their actions; and the camera has power over the photographers, it programs their acts' Vilém Flusser, Towards a Philosophy of Photography (Reaktion, London, 1983) 30.

${ }^{82}$ For Joseph Raz, the autonomous person 'is a (part) author of his own life. The ideal of personal autonomy is the vision of people controlling to some degree, their own destiny, fashioning it through successive decisions throughout their lives'. The Morality of Freedom ( $1^{\text {st }}$ Edition, Oxford University Press, 1986) 369. This indicates that an element of individual control is required over decisions taken.

${ }^{83}$ This is supported by findings from the LPS; Ofcom Research which found that seven out of ten people think that photos and images of people should not be shared without the permission of the people in the image: Ofcom, 'Communications Market Report' (2017) $34<$ https:/www.ofcom.org.uk/research-and-data/multisector-research/cmr/cmr-2017> accessed 12 September 2019.

${ }^{84}$ Under the GDPR (n 26) and the Data Protection Act 2018.
} 
Given the potential longevity of information shared online, especially through social media, alongside consent, social norms and education could play an important role in improving the situation. As one interviewee, a Police Officer, described in relation to being 'tagged' in photographs:

You haven't got a lot of control over that have you? You've suddenly got this portal into the world that anybody can pretty much put any photograph on there they want, as long as it doesn't breach sort of you know the tastes or standards and pretty much there isn't much you can do about it is there?

Another interviewee spoke of how he had recently seen a change in approach towards photography and the sharing of images, with individuals more willing to refrain from sharing images at the request of others, commenting how:

I notice, for example in social situations, you know when we're with other friends who have kids, they're all sort of taking photos, it's become a thing now to say “Look, don’t put these photos up on Facebook please”, people agree to that (Activist). At the same time, there is the ongoing parallel development of the emergence of privacy in public places, ${ }^{85}$ which further serves to strengthen the individual's position in respect of their autonomy and choice over what happens to their image, particularly online. If, as a result of education and social norms, the potential consequences of photography are better understood, this would serve to encourage more responsible taking and sharing of images in the future.

\footnotetext{
${ }^{85}$ See for example Peck v UK [2003] EHRR 41 and Weller (n 48).
} 
Whilst the introduction of image rights would undoubtedly strengthen the position available to famous individuals or public figures, for the reasons outlined above, this would be of limited use to the everyday person who does not have either the financial backing or public status usually required to rely upon such a right. Whilst it is not implausible that the effect of social media could render the everyday person a 'celebrity' or 'public figure', this is not an adequate basis on which to form an action and the introduction of image rights would not be of relevance to the ordinary person unless the application of these was construed far more broadly than is seen in other jurisdictions (e.g. the US), or there is a change in culture which encourages a more privacy-friendly environment. Such a development would, however, be met with significant resistance from both the media and photographers more broadly, due to the implications for freedom of expression.

The reach of the existing laws has been outlined in the discussion above. Whilst they have significant limitations, the plethora of laws already in existence deals with a number of situations which would not be benefitted by the introduction of image rights, and therefore education and social norms may provide a more preferable solution. Particularly in terms of social media, an individual may merely be looking for an effective option to control/remove unwanted images, rather than a legal response. Greater awareness as to the potential consequences of posting images online would encourage more responsible sharing in the first place, ${ }^{86}$ which could be combined with the use of privacy nudges to think about the consequences of sharing images ${ }^{87}$ along with social norms that would see it become usual practice to remove images at the request of the 'photographed' where taken without consent.

\footnotetext{
${ }^{86}$ For example through greater education in schools. Projects such as the 5Rights initiative aim to do this: 5Rights, 'About Us' < https://5rightsframework.com/about-us.html>.

${ }^{87}$ See for example Yang Wang and others, 'Privacy Nudges for Social Media: An Exploratory Facebook Study' (ACM Press 2013) 770 <http://dl.acm.org/citation.cfm?doid=2487788.2488038>.
} 
All these measures would collectively give more control to the 'photographed', whilst retaining the freedom to photograph. 